\title{
Table of legislation
}

\section{National Legislation}

Carriage of Goods by Sea Act 1924

(United Kingdom) 129

Carriage of Goods by Sea Act 1936 US COGSA 1936 (United

States of America) ...... 187, 202

Dutch Civil Code (Burgerlijk

Wetboek) 1992 66

German Commercial Code

(Handelsgesetzbuch) 1900 .... 66

Harter Act 1893 (United States of

America) 15

Merchant Shipping Act 1894

(United Kingdom) 176

New Zealand Shipping and Seamen Act 1903 16

Norwegian Maritime Code 1994

(Lov om sjфfarten), Act No 39

Sea Carriage of Goods Act 1904

(Australia) 16

Swedish Maritime Code (Sjölag), 1994:1009 189, 201

Water Carriage of Goods Act 1910

(Canada) 16

\section{EU Legislation}

Agreement between the

Intergovernmental Organisation

for International Carriage by Rail

and The European Union on the

Accession of the European

Union to the Convention

Concerning International

Carriage by Rail (COTIF) of 9

May 1980, as Amended by the

Vilnius Protocol of 3 June

1999
Consolidated Version of the Treaty on the Functioning of the European Union, Official Journal of the European Union, C 83/47, 30 March 2013, Vol. 53 (TFEU) ..... 237, 241, 242, 243, 245, 247, 249, 276

Council Decision 93/628/EEC of 29 October 1993 on the creation of a trans-European combined transport network ............... 284

Council Directive of 17 February 1975 on the establishment of common rules for certain types of combined road/rail carriage of goods between Member States (75/130/EEC) with further amendments 283

Council Directive 92/106/EEC of 7 December 1992 on the establishment of common rules for certain types of combined transport of goods between Member States, Official Journal L 368, 17 December 1992 ... 283

Council Regulation (EC) No 2027/97 of 9 October 1997 on air carrier liability in the event of accidents, as amended 260

Decision 94/69/EC of 15 December concerning the conclusion of the United National Framework Convention on Climate Change

(OJ 1994 L 33, p. 1) 256

Decision 2002/358/EC of 25 April 2002 concerning the approval, on behalf of the European Community, of the Kyoto Protocol to the United Nations 
Framework Convention on Climate Change and the Joint fulfillment of commitment thereunder (OJ 2002 L 130, p. 1) 256

Directive 2008/101/EC of the European Parliament and of the Council of 19 November 2008 amending Directive 2003/87/EC 256

Regulation (EC) No 889/2002 of the European Parliament and of the Council of 13 May 2002 amending Council Regulation
(EC) No 2027/97 on air carrier liability in the event of accidents 260

Regulation (EC) No 261/2004 of the European Parliament and of the Council of 11 February 2004 establishing common rules on compensation and assistance to passengers in the event of denied boarding and of cancellation or long delay of flights, and repealing Regulation (EEC) No 295/91 $9,260,261$ 